\title{
Calvin and the Corpus Christianum
}

\section{B J ENGELBRECHT}

\section{The expression Corpus Christianum}

The expression Corpus Christianum is not a much-used one in the neighbourhood of Calvin and his theology. It is a phrase more frequently connected with the name of emperor Constantine the Great and is more specifically used to describe the position, influence and status of the post - Constantine church (throughout the Middle Ages) in relation to the totality of life (and especially public life) in all its facets.

Although some scholars like A A van Ruler do favour the term Corpus Christianum to denote his Calvinistic theological system of theocrasy, ${ }^{1}$ the expression Corpus Christianum is in my opinion applied only in metaphorical sense to Calvins vision on the relation between the church (or Christian faith) on the one hand ánd society, public life, political life and the state on the other hand. The main cause for the application of this term to certain aspects of Calvins theology, is of course his attempt of the practical realization of these views in Geneve.

\section{The meaning of the expression Corpus Christianum}

For the sake of clarity it is perhaps best to give a short description of the original meaning of the phrase Corpus Christianum. The historical background of this term is that after emperor Constantine the Great a beginning was made to christianise the whole world. ${ }^{2}$ In this process the reign of God in Jesus Christ over everything, the regnum Christi, was taken seriously.

I do not think that we can have any objection against the motive of christianisation of the world and against the importance of the concept reign of Christ and Kingdom of God in this respect. As a matter of fact both the Dutch Reformed Church of the Netherlands in its pastoral letter ${ }^{3}$ and professor Brillenburg Wurth $\mathrm{W}^{4}$ take as their point of departure the Kingdom of God, when speaking about our topic. The mentioned Church says about the Kingdom of God: "Therefore this central word from the biblical preaching is as appropriate as no other to guide our thoughts in speaking about the relation between church and politics". ${ }^{5}$

But now: For the post- Constantine church the reign of God over the world meant in practice that all things in the world was subjected to the church and to her spiritual and worldly head, the pope. Thus 
the whole society and every expression of society such as economics and culture, was bound to the church and received its imprint, its whole character from the church. ${ }^{6}$ The biblical distinctions between church and state, gospel and law, election and freedom was neglected. The result of this was eg. that any deviation from the doctrine of the church (such as heresy, unbelief and Judaiism) was apposed and punished by coersive measures of the state. ${ }^{7}$ The church as institute was predominant while the state was in fact the servant and pack animal of the church.

In short: The original meaning of the Corpus Christianum was the ecclesialising of society to such an extent and in such a way that it was termed ecclesiocracy.

It is clear that Calvin had to determine his position towards this important issue.

\section{The basic issue and alternative ways to formulate the problem}

(a) If we take the reign of God in Jesus Christ over the whole world as our point of departure, the basic issue that we must examine in Calvins theology is: how and by what means does this reign take concrete form and realisation in the world, in society and in all facets of human life? From this basic question other questions arise such as: Is it the responsibility of the church to contribute towards the becoming concrete of the reign of God over everyone and everything? If this is the task of the church, in what way should the church fulfill this task? Is the only task of the church the preaching of the gospel or does the church have a "political" responsibility which necessarily implies action by the church? If "political" action is implied, should the church exercise it by the engagement of the church as institute or only through the independent political responsibility and engagement of her members who has grown to adulthood with respect to their faith. In this context the question of the responsibility of the civil government in this matter nearly automatically arises as does the related question of the relation between church and civil government. This relation can of course be seen from various angles so that one may eg speak of a statechurch ("staatskerk") or sometimes of the ideal of a churchstate ("kerkstaat"). It is clear that not only the view on the church and on the relationship between church and civil government will effect the ways and the means by which the reign of God, the theocracy, is going to become concrete, but that also the concept of the state will be of prime importance of this respect. Relevant questions are: Should the civil government be a neutral or a God-acknowledging, even a positive Christ-confessing state? And if this is the 
case, what should its attitude and course of action be towards individuals and groups who have divergent views? Here the question of tolerance (its grounds, its nature and its limits) comes into the field of vision.

We have thusfar frequently used the expression: the becoming concrete of the reign of God, the theocracy, in the world. But it is clear that the world, especially the world of people, is not an amorphous mass, but that there are certain given, sometimes natural, articulations such as family, group and eventually the nation ("volk"). Let us assume that the church has a responsibility in the process of realisation of the theocracy, should she work along the lines of these given articulations? In this context the following set of important questions come to the fore: Should the church be church of the nation ("volkskerk") and in what sense? What is the meaning of Israel in this connection and what relevance does the fulfillment of the promises also the promises of the kingdom of God in the New Testament, the fulfillment of the law in the gospel of Jesus Christ have on this situation?

(b) After this has been said we can summerise as follows:

(i) The basic question is: How and by what means should the reign of God in Jesus Christ over the whole world and over all facets of society and human life become concrete?

(ii) Operative words and phrases concentrated around this issue are: church; statechurch; church of the nation (volkskerk); Israel as model; fulfillment in the New Testament; proclamation or action; action by the church as institute or action only through its members and Christian associations; civil government; a neutral God acknowledging and Christian state; tolerance; the relation between church and state.

(iii) After this preliminary survey of the field and of the issues involved, we can now proceed one step further and give a synopsis of the theological views of Calvin on this matter within its historical setting.

\section{The theological views of Calvin on the "Corpus Christianum".}

(a) The formal point of agreement between Calvin, the Roman Catholic Church, Luther and the Anabaptists is that all of them had an intense interest in the reign of God, in his Kingdom. The differences between them circles around four points: the first is their respective concepts of the Kingdom of God; the second is their various views on the relationship between the Kingdom and the church; the third point of difference is their notion of to 
what extent the Kingdom has relevance for society and the final point is how the reign of God should become concrete in life and society.

(b) We have already seen that for the Roman Catholic Church in Calvins time the Kingdom of God and the Church coincided to such an extent that there came into being an ecclesiocracy wherein all aspects of life and society, even civil government, fell under the power of the Church to such an extent that we can speak in this respect of a worldly Godstate ("aardse Godstaat").

(c) At this stage we can say that Calvin over and against Rome ${ }^{8}$ in the first instance broke away from the Roman Catholic scheme of the relationship between nature and grace where grace functions as the elevatio naturae, the raising of nature to a higher order. In the second place Calvin did not want anything to do with the intertwinement, the merging of ecclesiastical and wordly power.

(d) Instead of nature and the elevation of nature by grace, Calvin spoke of creation and re-creation of everything in Jesus Christ. The statement of Calvin on the question why God created the world, is well-known: "God created the world that it should be a show-place (an exhibition, a theatre) of his glory". ${ }^{9}$ Recreation now meant to Calvin: restitution, restoration in Jesus Christ, of everything and of all relations to their original state and meaning as was intented by God with their creation. ${ }^{10}$ The fall and sin effected creation in its totality and recreation means the restoration of the world of life and of society in its totality, in all its articulations. ${ }^{11}$

(e) Calvin also expressed these thoughts in terms of the reign of God in Jesus Christ, in terms of the Kingdom of God. Creation's purpose was, as we have seen, to reflect Gods glory, the glory of his reign, of Him as sovereign Ruler over everything created. Fall and sin of course meant to Calvin the corruption of nature, also of human nature; but it also meant autonomy. ${ }^{12}$ Autonomy in this context meant something total and absolute; it impued the withdrawal of everything (such as nature, the reflection on nature i.e. science, human life in all its facets such as history culture and art) from the nomos, the authority and reign of God; subsequently it meant that finally the whole of creation and all spheres of human life and activity are subject to and behave according to their own laws. For nature it meant the laws of nature; for economics, politics and art the own, independent laws of economics, politics and art. If fall and sin meant autonomy, re-creation and reconciliation in Jesus Christ meant restoration of the original theonomy, the original reign and rule of God. Restoration for Calvin thus meant renovation, renovation not only 
for our personal lives but also of public life, in its full breadth and width, also of the political order. Restoration and renovation meant for Calvin that a Christian cannot have peace with the contrast between the Word of God, the Word of reconciliation and renovation on the one hand and the facts, the facts in their unreconciled state. Taking the Word as his basis Calvin attached the facts to create theocracy, a holy order of life to the honour and glory of the sovereign God of all creation. ${ }^{13}$

(f) Primarily this holy order of life to the honour and glory of God, was the church. The church is, according to Calvin, the first of the media externa, the external means, by which God calls us to communion with $\mathrm{Him}$ and through which He preserves us in this communion. ${ }^{14}$ Christ reigns in and over his church immediately by his Word and Holy Spirit and mediately through the offices ("ampte") in the church. This implies three things:

(i) The church must be a holy community in which the regnum Christi must become apparent.

(ii) The church must proclaim Gods glory and reign over the whole creation.

(iii) But the church is also an external medium in the hands of God by which He grasps the life of each individual and of all provinces of life and subjects them to His sovereignity.

(g) In our exposition thusfar of Calvin's views against that of Rome, we encountered two important concepts:

(i) The first was the term "creation" in his description of redemption in terms of creation - recreation.

(ii) The second was the term "law of God" (when Calvin stated that instead of autonomy, all things must be subjected to the law of God, the theonomy and eventually to theocracy).

1 consider these concepts important because they play an important part in establishing the differences between Luther and Calvin in the matter we are discussing.

(h) Looking at Luther, ${ }^{15}$ we find that for both Luther and Calvin the sum of true wisdom consisted of the knowledge of God and of ourselves. Knowledge was to both of them practical and edifying; existential and not speculative; not a knowledge in terms of "Rhetorik" but of "Tatsachen" coming forth from the Word of God which testities of the revelation of God in Jesus Christ. We must therefore speak about God in the category of relation, eg of the personal relation between God and man, and not in the metaphisical and logical category of substance. Departing from here, Luther began by asking the egocentric question: How can I find a merciful God? He received the theocentric answer: Only through God in Christ where everything sing about the glory of God. Luther took the issue of the glory of God just as seriously 
as Calvin did, but for Luther the song of God's glory found its rendering in the escatological song of the Lamb. It is true that Luther found, just as Calvin did, that the God of the Scripture is our Father. But in addition to this he saw God more as Judge and man more as sinner and as a justified sinner. Calvin on the other hand saw God more as Creator and Lord and man as fallen creature and as redeemed child. As we have already pointed out, Calvin, thinking in terms of creation ánd of redemption as recreation,found the rendering of the song of Gods glory in the ascatological song of the Lamb, but also in the service of God in every facet of life. This service is demanded by and is regulated by the Law of God. ${ }^{16}$

The concept of Luther about the reign of God in the present dispensation eventually found shape in his doctrine on the two regiments. The one is the regiment of Christ and the other the regiment of the world. God as supreme Ruler uses both to govern the world but with respect to each one he uses different ways and means and does it in a different spirit, for each one has its own nature, structure and laws and its own justice. The " $j u-$ stitia spiritualis" was the justice of faith with the eye on eternal life; the "justitia civilis" was the civil justice of the law, but not of the gospel, to rule the sinful world. The Christians, belonging to the spiritual regiment do not need the law. The dualism in Luthers concept of the two regiments not only followed from his dualism between law and gospel but to a certain extent also from his dualism between reason and revelation. In the ordo civilis the law and reason is necessary; in the ordo spiritualis gospel and revelation are the operative words.

(i) In the theology of the Anabaptists ${ }^{18}$ the concept Kingdom of God as well as the reality of the law of God played an important role. Both Calvin and the Anabaptist were convinced that the belief in the Kingdom and reign of God included the demand of concrete sanctification of life. Both regarded the law as necessary in this process of sanctification, in the process of the becoming concrete of the reign of God. Calvin however objected against the legalistic way in which the Anabaptists interpreted the law; fundamentally they reinterpreted the gospel of Jesus Christ as a nova lex, a new law so that the pharisaic error of holiness and redemption through our good works became eminent. For Calvin the law had its lawfull place within the limits of the doctrine of our gratitude and it functioned in such a way that it never impeded the joy and the freedom of the gospel.

But the differences between Calvin and the Anabaptists on the issues of the reign of God and the subsequent sanctification of life, went deeper and had a wider scope than is apparent just in 
the issue of the law. The Anabaptists were not prepared to wait in faith and with the patience of faith on the coming and manifestation of the kingdom of God. Their intention was to establish the kingdom of God, the new Jerusalem here and now not only with spiritual means but also by means of radical external, political and social revolution. In their proudrevolutionary anticipation of the Kingdom, they distanced themselves from the present, sinfull world and they withdraw themselves from taking any responsibility for it. This was especially true of the civil government.

(j) As it shimmered through from time to time, Calvin also had an escatalogical view on the reign of God. He knew that the full reality of redemption, of re-creation as total renovation, of the new creation, will only appear after the end of time; but that did not prevent him from taking full responsibility for the sanctification of life and society in the present dispensation. In this way Calvin maintained the biblical dialectical balance between the presence and the escatological extance of the Kingdom of God; Luther, and especially later on some Lutherans, neglected the presence in favour of the extance; the Anabaptists anticipated the extance and tried to transform it in a revolutionary way into pure presence.

(k) In our discussions thusfar it also became apparent that if we speak about our topic, we cannot avoid speaking about civil government and the mutual relationship between civil government and the church. We have already seen that in the ecclesiocratic view of the "Corpus Christianum" by Rome, the civil government became servant and packanimal of the Church. Looking at Luther we found the doctrine of the "twofold regiment" each with their own nature, governing laws and justice. Within the circle of the Anabaptists civil government is part of the sinful world and ought to be replaced by the reign of God and the community of the new Jerusalem here and now. Calvins position against this background and in this context is that he not only regarded the church and the sacraments as the media externa by which God calls us into and maintains us in communion with $\mathrm{Him}$, but that he also counted the civil government as belonging to these external means. ${ }^{19}$ Calvin takes position against Rome when he speaks about the twofold government in man and makes clear that they are two truely distinct and differentiated entities. He also takes position against the Anabaptists and calls them "frantic barbarous men who are furiously endeavouring to overturn the established order by God". ${ }^{20}$ He says that they, "hearing that liberty is promised in the gospel, ... think that they can receive no benefit of their liberty as 
long as they see any power placed over them". He then concludes making two remarks: Firstly: "that spiritual liberty is perfecty compatible with civil servitude", and secondly: in our pilgrimage on earth we need certain aids to attain true piety and "those who take them away from man, rob him of his humanity". Civil government has two main objectives: "that a public form of religion may exist among Christians and humanity $(h u-$ manitas) among men. He says that his statement that civil government has "the task of constituting religion aright" may surprise some people. But by this statement, he says "I no more than formerly allow men at pleasure to enact laws concerning religion and the worship of God." Civil government cannot make laws about religion at pleasure, but must use the law of God to guide them to make laws and take steps "to prevent true religion, which is contained in the law of God, from being with impunity openly violated and polluted by public blasphemy". From what has been said, the issue is clear: Civil government must use both tables to take care "that a public form of religion may exist among men" and it must use at least the second table to ensure that "humanity exists among men". In reality a civil government can be neutral or even anti-religious, but according to its biblical intention it ought to be christian. Like the church it was instituted by God, it received the instruction of God to care for humanity among men, but also to protect and promote the public form of Christian religion and it received the authority and means of God for execute these mandates. But civil government and the church are clearly two different entities, each having its own nature, its own calling, its own means, its own authority and each one must take its own responsibility as an independent institution for its own decisions. In Geneve, even "from 1555 onwards when the Government of the Republic became a full-fledged theocracy" the church under Calvins guidance did advise the civil authorities lent never prescribed to them. ${ }^{21}$

(1) Formerly we said that Calvin thought about redemption not only in terms of restoration of creation to its original intention, but that he also thought of fall and sin in terms of autonomy and of sanctification of life and society in terms of bringing them back to the law and reign of God. This was also one of the perspectives from which he saw civil government. Civil government and the art of politics are not autonomous, ruled by its own inherent laws; politics is not merely a technical concern, governed solely by social and economic factors and laws, but politics has an anthropoligical and ethical basis. "Since the Christian State has an ethical as well as a political basis and is 
invested with an ethical function, it is, or ought to be, bound in its action by the ethical principles applicable to the life of the individual Christian" ${ }^{22}$ These ethical principles are to be found in the law of God. Therefore: Not autonomy but theonomy. In this way the civil government must make, of course in its own way and sphere, "its contribution to the realisation of the Kingdom of God". ${ }^{23}$ Although the first concern of civil government is the shaping of public life (taking the second table of the law of God as its basic point of departure), Calvin also regarded to state as the political order whereby God preserves the world for his Kingdom.

(m) It is clear that the primary field of activity of the civil government is the nation (volk). Calvin also regarded this natural articulation in the living together of people, as being of importance to the church in establishing of the reign of God in the world. Calvin was convinced that the most effective way to make the reign of God concrete in the world, was when the civil government of a nation and the church of that nation, the volkskerk co-operated, each by its own ways and means, to achieve this objective. ${ }^{24}$ Members of the General Assembly at Geneve ${ }^{25}$ and later $\mathrm{dr} \mathrm{Ab}$ raham Kuyper ${ }^{26}$ critisised Calvin in this respect, saying that he tended to equate the nation with Israel and laid to much emphasis on the law. One of the members at Geneve spoke of a return to Judaïsm and said: "we are now not under the law, but under grace". In all fairness to Calvin let us firstly look at what Calvin did not say and also at what he did say in this respect: Calvin never equalised a-nation-in-our-sense-of-the-word with Israel as nation. Calvin was very conscious of te unique and irrepeatable position of Israel in world history where the nation was simultaneously the church and the church the nation. ${ }^{27}$ Calvin never taught that every member of the nation can automatically be a member of the church. He did teach that the church must address itself in the proclaiming of the gospel to the whole nation and that it is the ideal that every member of the nation should become a member of the church. But this becoming a member of the church can never happen except through the channel of the atonement through Jesus Christ and by faith; it can never happen, Calvin said, except by the means that God ordained for entering his church. Calvin never said that the nation was the church and the church was the nation. He never said that the church was there for the nation, but he did say that the nation was there for the church - that the nation is a very effective channel for the church to make concrete something of the reign of God. Calvin did say that the church should address itself in word and deed to the whole nation; that the church should work 
nationwide and nationwise. ${ }^{28}$ By this last term: nationwise, he meant two things: Firsty that not only should every member of the nation personally become a member of the church, but that the whole national order should be christianised. Secondly Calvin was convinced that when a nation accepts Christ, the whole life of the nation in its breadth and width will experience the blessing of this evangelical obedience, of this rennovation of human life, also of the life of the nation.

(n) Another point of controversy concerns the method that the church has to use in making visible and real something of the reign of God in life and society. This issue became acute and was sharply formulated in the theology of dr Abraham Kuyper. According to Kuyper ${ }^{29}$ the Nederduitsch Hervormde Kerk at that time was not only volkskerk which uncritically included the masses, but one of its main errors was that it attempted to christianise life and society as an institute through her offices. Thereby they invited the world into the church with the result that the church became secularised instead thereof that the world became christianised. In this way, according to Kuyper, the necessary biblical antithesis between church and world, between church and civil life and government, between holy and secular disappeared. The church must be kept holy. This can be done by distinguishing between the church with its offices as institute, sovereign and closed in its own circle, and the church as organism within which Christ works directly on the various fields (like science, art, politics) and within which the office of each believer operates through various christian organisations. In the way Kuyper meant that the world could be christianised without ecclesialising the world while the church remains holy.

It is clear that in its consequent form this view leads to a neutral state. Choisy said about the Calvins Academy of Geneve: "La primiére manifestation exterieure du triomphe définitif du système théocratique calviniste" ${ }^{\prime \prime} .{ }^{30}$ We do not have time to look at the academy more closely. It may be very instructive for our theme. One thing is certain however, and that is that it did come into being by the church as organism, but by the church as institute. I think that the same can be said of the theocracy of Geneve which John Knox called "the maist perfyt schoole of Chryst that ever was in erth since the dayis of the apostellis". And herewith I think that I have shortly stated and expounded all the main issues of our theme. 


\section{NOTES}

For the sake of easy survey and clarity we used and quoted only from an absolute minimum books and articles on the Corpus Christianum

1. A $A$ van Ruler, Heeft het nog zin, van "Volkskerk" te spreken, Wageningen 1958, p 11-12.

2. Cf I $N$ Bakhuizen van den Brink en J. Lindeboom, Handboek der Kerkgeschiedenis, 3de druk 1946, D1 I, p 111 seq.

3. De Politieke Verantwoordelijkheid van de Kerk, 1964, p 6-11 (Quoted as: $N H$ Kerk, $P V, p \ldots$...

4. $G$ Brillenburg Wurth, Calvijn en het Koninkrijk Gods (in Vier Redevoeringen over Calvijn, Kampen 1959), p 55 seq. (Quoted as Wurth, p ...)

5. NH Kerk, P V, p 6

6. Wurth, p 59-60.

7. N H Kerk, P V, p 20.

8. Wurth, p 59-63

9. theatrum gloriae dei. cf et Inst I, 14, 20-21.

10. Cf Inter al comment Calv in Rom 8:19-22, Ef 1:4-12 et Col 1:18-20.

11. Cf Arnold $A$ van Ruler, Das Leben und Werk Calvins, p 89-94 (in Calvin-Studien 1959, Neukirchener 1960).

12. Cf eg comment Calv in Gen 3:6.

13. I Koopmans, Onder het Woord, uitgewersmpy. Holland 1949, p 281. (Quoted as Koopmans, p...).

14. I Calvinus, Inst $\mathrm{N}, 1,1$.

15-16. A $D$ R Polman, Calvijn en Luther (in Vier Redevoeringen over Calvijn, Kampen 1959), p 44 seqq. (Quoted as Polman, p...)

17. Cf Wurth, p 60 seq.; Koopmans, p 158; $M$ Luther, Von Weltlicher Obrigkeit.

18. Cf Wurth, p 63-67.

19. J Calvinus, Inst $X X, 1,1$.

20. This and the following short quotations all come from Inst IV, 20, 1-3.

21. Cf James MacKinnon, Calvin and the Reformation, Longmans 1936, p 162 seq.

22. MacKinnon, Op cit., p 86.

23. Do.

24. S / Botha, Die Volkskerk, HAUM, Pretoria 1973. Especially p 5-9 (Quoted as Botha, p...).

25. Mackinnon, Op cit., p 168.

26. Botha, p 17 seq.; Wurth, p 69 seq.

27-28. Cf Botha inter alia p $5-9$ et $28 \mathrm{seq}$.; Koopmans, p $278 \mathrm{seq}$

29. Cf Botha, p $17 \mathrm{seq}$.

30. La Théoratie à Genève, 1897, p 215 